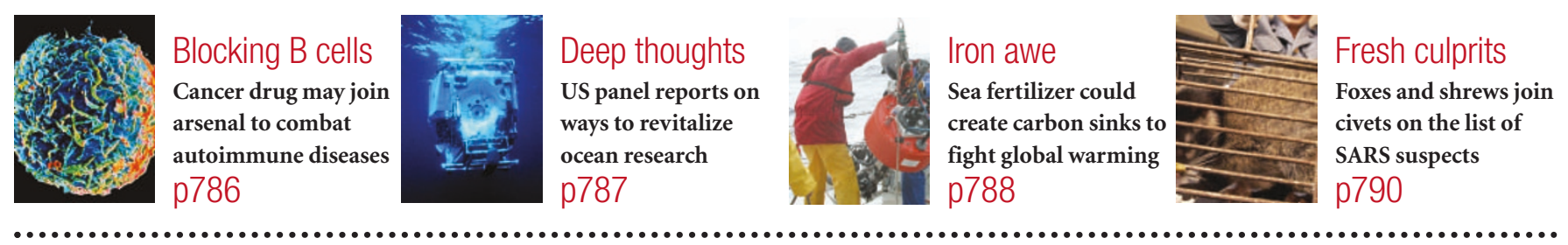

\title{
Boston locals fight government scheme for bioterror defence lab
}

\section{Rex Dalton}

Plans to build a \$178-million infectious diseases laboratory at Boston University have triggered strong objections from local scientists and residents, threatening the US government's plans to shore up its defences against biological agents.

Around 150 scientists from the Boston area released a letter on 13 April calling on city officials and Boston University trustees to halt plans to build the National Biocontainment Laboratory - a biosafety level 4 facility that could handle the world's most dangerous pathogens - in the city's South End.

They say that they object to the facility on scientific, safety and political grounds, and have joined residents' groups who claim that the laboratory is being foisted on one of Boston's poorest neighbourhoods, next door to Boston University Medical Center. The neighbourhood, once the most famous Irish ghetto in the United States, is now populated mainly by African Americans.

Boston City Council was due to hold a public hearing on 20 April on the safety of the proposed laboratory. But three of the council's 13 members have already declared

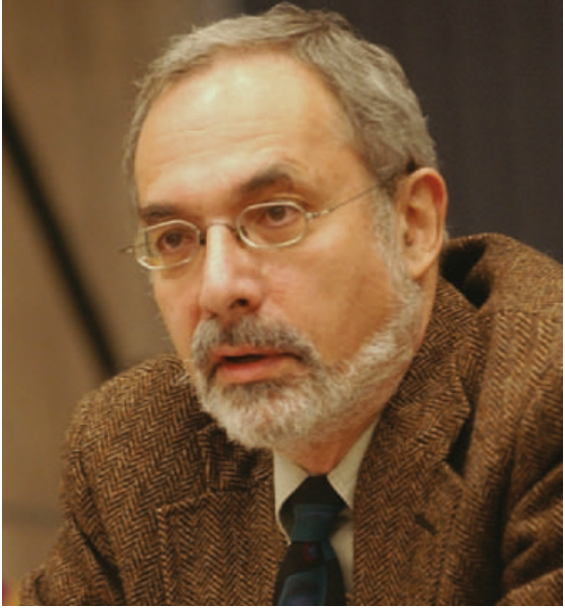

David Ozonoff: retracted support for biodefence lab, saying scientists were being misled.

their support for a proposed municipal law that would outlaw the facility. Last week, anxious university administrators were trying to rally public support for the project, and its supporters plan to run newspaper advertisements in its defence.

David Ozonoff, a physician at Boston University and former chair of its environmental

\section{Europe overpays research expenses}

Alison Abbott, Munich

Over a fifth of the expenses claimed by researchers funded under the European Commission's Fifth Framework Programme of Research (FP5) should not have been paid, according to the European Court of Auditors.

The court studied 28 representative projects from the $€ 13.7-$ billion (US\$16.3billion), five-year programme, which ended in early 2003. Its report, published on 20 April, found a $21 \%$ error margin in the payouts.

Typical cases include the purchase of scientific equipment that was not covered by the terms of the grant, although the auditors say that the mistakes are due to mismanagement rather than fraud. More careful screening of the expenses could have avoided the problem, the court says.

The commission worked closely with the court during the audit, which began more than a year before FP5 ended. Realizing the problem, it inserted a requirement for external auditing of grantees' eligible costs into its follow-up Sixth Framework Programme.

But this extra rule is a burden for scientists, concedes commission spokesman Fabio Fabbi. "The commission is criticized for loopholes that allow excessive spending, but also for being overly bureaucratic," he says, "We have to strike a balance." The FP5 rules were already "an unnecessary complication for participants", according to the auditors. health department, says he was originally in favour of the project, but had turned against it because administrators were "misleading" the scientific community. Military and lawenforcement agencies would be able to "stipulate whatever they want" from the facility, he claims, adding that the lab's existence could increase the likelihood that dangerous pathogens would end up in terrorists' hands.

Mark Klempner, a physician, associate provost of the university and principal investigator on the laboratory project, declined to discuss the objections. But a spokeswoman for the university said that it was dedicated to creating a dynamic and safe facility.

The Boston laboratory is one of two mainstays of the National Institutes of Health's response to the threat of bioterrorism; a similar containment laboratory is also to be built at the University of Texas in Galveston. A federal public hearing in Galveston on 31 March attracted only a single dissenting voice.

Awards to construct the two facilities were made last September by the National Institute of Allergy and Infectious Diseases after an intense competition between possible host universities. Nine biosafety level 3 laboratories were also announced by the agency.

Officials at the National Institutes of Health say they are confident that the laboratory will still be built; university officials have hired architects for the project.

Sheldon Krimsky, a professor of urban planning at Tufts University in Medford, Massachusetts, and an opponent of the project, says it is too early to tell if the Boston site is doomed. "This is a top-down thing, presented by the university to the community," he says.

Objectors complain that the lab should not be placed in a densely populated area where so many residents lack basic health insurance. "Scientists should be ashamed that they are taking advantage of poor people," says Daniel Goodenough, a cell biologist at Harvard Medical School.

But the university argues that the laboratory will bring jobs and tens of millions of dollars in research funding to a hard-pressed corner of the city. 